Golden Gate University School of Law GGU Law Digital Commons

1998

\title{
Unification of Private Law and Codification of International Law
}

Sompong Sucharitkul

Golden Gate University School of Law, ssucharitkul@ggu.edu

Follow this and additional works at: http://digitalcommons.law.ggu.edu/pubs

Part of the International Law Commons

\section{Recommended Citation}

3 Uniform Law Rev. 693 (1998)

This Article is brought to you for free and open access by the Faculty Scholarship at GGU Law Digital Commons. It has been accepted for inclusion in Publications by an authorized administrator of GGU Law Digital Commons. For more information, please contact jischer@ggu.edu. 


\title{
Unification of Private Law and Codification of International Law
}

\author{
Sompong Sucharitkul *
}

\section{I. - INTRODUCTION}

Unification of private law is principally a task undertaken by the Institute for the Unification of Private Law (UNIDROIT), while the codification and progressive development of international law constitute the dual function of the International Law Commission (ILC). The purpose of this brief essay is to illustrate how in several areas and in more aspects than one, the activities of UNIDROIT and the achievements of the Commission can be found in the same or similar, if not indeed identical, overlapping areas of study.

It is not intended to attempt a comprehensive survey of past performance and experience of the two norm-formulating agencies. Both are inter-governmental in their constitution, while each working group and individual member acts in a personal, independent and expert capacity, not directly under the instruction or control of any Government, nor in any representative function. It is accordingly opportune to examine the various aspects of these two law-generating bodies and to compare, and in some cases contrast or distinguish, the aims and purposes of their functions, the different approaches and methods of work adopted for the study and preparation of draft articles in some selected topics that appear highly interesting and broadly similar, and the usefulness and utility of their final products, findings or recommendations.

It is logical to begin at the beginning by observing the constituent instruments creating the two norm-formulating bodies, one as an independent organization by itself and the other as a subsidiary organ of the General Assembly of the United Nations coming under the general supervisory power of the Sixth (Legal) Committee of that principal organ of the $\mathrm{U}$ nited $\mathrm{N}$ ations.

\section{II. - CONSTITUENT INSTRUMENTS}

The aims and purposes or the object and purpose of an international organization are invariably contained in the Statute or Charter of what is otherwise collectively and generically known as the constituent instrument of the Organization. Its functions and the activities to be conducted are envisaged, if not specifically provided, in the same instrument by which the organization is constituted.

Article 1 of the Statute of the International Law Commission provides:

* Associate Dean and Distinguished Professor of International and Comparative Law, Golden Gate U niversity School of Law, San Francisco (USA); Ambassador (retired) and former member of the International Law Commission; M ember (Thailand) of the Institute of International Law; Correspondent of U NIDROIT.

This contribution is dedicated to the memory of Malcolm Evans, late Secretary General of U NIDROIT. 
1. The International Law Commission shall have for its object the promotion of the progressive development of international law and its codification.

2. The Commission shall concern itself primarily with public international law, but is not precluded from entering the field of private international law.

It is clear from the outset that the Commission is primarily concerned with public international law but is not restrained from venturing into the field of private international law whenever and wherever its primary concern requires. It will be seen how frequently and how ordinarily the application of the rule of international law or public international law essentially affects the rights and interests protected by private law or the outcome of the application of a rule of private international law.

On the other hand, UNIDROIT, or the International Institute for the Unification of Private Law, was initially affiliated to the League of $\mathrm{N}$ ations. The founder of the Institute, M inister Vittorio SCIALOJA, Italy's first Permanent Delegate to Geneva, concluded an agreement whereby the Italian Government provided premises in Rome for the Legal $O$ ffice of the League of Nations.

In the 1930s, René DAVID and Mario MATTEUCCI were the driving force in the field of private law, and on the basis of the treaty concluded between member States the Institute was able to weather the turbulent storm of World War II and resume its activities with renewed vigor by 1945 . At that time, Matteucci became its Secretary General until 1974, when he was appointed President of the Institute. That office was subsequently passed on to Riccardo MONACO and Luigi FERRARI BRAVO respectively. The post of Secretary General of the Institute was held by Malcolm EVANS until recently, and at present W alter RODIN Ò is Secretary General ad interim.

Under its Statute, the Institute is administered by a Governing Council consisting of experts seconded by member Governments, supported by its staff and invited expert consultants serving as corresponding collaborators, or correspondents for short.

The Institute has traditionally tended to work for the unification of rules of substantive law, incorporating conflict of laws rules in its texts of uniform law only incidentally. As an international organization in its own right, with independent status, the Institute can concentrate more on the strictly legal and technical aspects than on the "political" implications of unification of private law. This technical approach is reflected in its practical choice of topics for study as contained in its Work Programme and in the methodology it has adopted to pursue its object and purposes.

In its choice of a particular topic to be included in the Work Programme, the Governing Council is ever so mindful of the objective requirements of the international community for unification in a particular area and also of the likelihood of reconciling existing differences in the various municipal legal systems and the possibility of a widely acceptable compromise solution.

While in theory, the objective of the Institute may be to achieve the widest measure of harmonization possible in the absence of unattainable uniformity of rules, suggested solutions often reflect a compromise so as to enhance the chances of wider acceptance by the global community. In some cases, the choice of the type of unification attempted as well as its sphere of application may fall on an instrument 
addressing exclusively trans-boundary situations or relations. In others, it may also cover domestic legal situations and relations of a purely internal character.

Based on a comparative study of existing rules in the various legal systems with the view to promoting unification, assimilation and harmonization of private law through intergovernmental negotiations and adoption of international instruments in the form of a convention or model uniform rules or laws, the Institute has succeeded in its principal sphere of activities in the preparation of uniform law rules. This objective can also be attained through other means designed to perfect methods employed in the unification of law. This includes in particular the maintenance and services of a law library of a vast collection of books and periodicals covering the widest possible range of countries in the most difficult branches of private law, especially trade law and commercial or business law, as well as private international law or conflict of laws and comparative legal systems and legislation.

\section{III. - OVERLAPPING AREAS OF INTEREST}

Although at first glance, the object and purposes of the two international normsformulating bodies appear to project two entirely separate, independent and isolated paths of activities to be pursued, with each in its turn subject to its own constituent instrument and mandated by its own statutory provisions and administrative machinery for the implementation of its tasks, a closer examination and a more detailed analysis of the respective functions and activities of the two bodies will reveal considerable overlapping and concurrence of studies. After all, the International Law Commission is not precluded from entering the field of private international law, which constitutes one of the traditional fields of study of UNIDROIT.

The next question to be examined is whether the areas of overlap are confined to the fields of private international law. The answer appears surprisingly to be clearly in the negative. The overlap is more real than apparent, more deep-rooted than superficial and certainly much further-reaching than anticipated ab initio.

A key that may help unlock the mystery of this riddle of the intricate interconnections between international law or the law of nations, in particular with regard to its codification and progressive development, on the one hand and the task of unification of private law on the other lies in the scientific search for the right path to identify the substantive rules of international law. The enigma of the law of nations finds its solution in the source of the law, i.e. the material as well as evidentiary sources of international law. This is where international law and private law have their common origin, their identical congenital ancestry.

Let us start from the premise that UNIDROIT (or the Institute) chooses topics of private law for intensive study which, upon analysis, show promising signs of assimilation, unification or possible harmonization of substantive rules, if not of the results of their application.

Since its inception, UNIDROIT has prepared over seventy studies and drafts, principally relating to the law of sale and kindred matters, the law of documentary credits, carriage of goods and passengers by sea, air and road, civil liability, the law of procedure and the tourist trade. Diplomatic Conferences have adopted several Conventions drafted 
by the Institute, such as the 1964 Hague Convention relating to the uniform law on the International Sale of Goods; the Brussels Convention on the Travel Contract (1970); the Geneva Convention on Agency in the International Sale of Goods (1983); the UNID ROIT Conventions on International Factoring and on International Financial Leasing (O ttawa, 1988); and the UNIDROIT Convention on Stolen or Illegally Exported Cultural Objects (Rome, 1995).

UNIDROIT has also adopted the "Principles of International Commercial Contracts" as an alternative to binding instruments, a non-legislative means of unification or harmonization of law. Indeed, in the field of contractual obligations, a certain measure of freedom of contract or autonomy of the parties is recognized in every legal system. As a consequence, the so-called binding instruments, whatever the form adopted, be it international treaty, codification convention or model law, appear to entail binding effect only upon the States participating in the Convention or adopting the model law in question. It is only incidentally that the private individuals or corporations negotiating and concluding a contract or business transaction are bound by the national legislation applicable to the contractual agreement. There is always available the choice of law clause that is a distinct option for the parties, unless the exercise of such option contravenes the mandatory norm of the forum or is repugnant to the public order of the forum State.

The fact that one of the forms in which unification or harmonization of private law may take place is that of Treaty and that it is as such governed by public international law of Treaties would appear to indicate beyond doubt that most endeavors to achieve uniform laws or harmonization of private law on a particular topic may depend on the adoption, conclusion, interpretation and application of Treaty provisions. This demonstrates in turn the use of public international law techniques to implement measures of unification and harmonization.

The sources of private law, including conflict rules, are to be found in the national legal systems and a comparative study of their substantive rules on a particular topic. To assess the likelihood of possible assimilation, unification and harmonization, comparative law techniques have been employed. As President Monaco has put it, "'uniform law' or unification of private law is truly a 'natural extension of comparative law'."

How then can the task of unification of private law be comparable to the mission of codification of public international law undertaken by the International Law Commission? The answer appears readily discernible from the sources of international law where the Commission must concentrate its search and discoveries. Under Article 38(1) of the Statute of the International Court of Justice, which forms an integral part of the Charter of the United Nations (1945), the sources of international law can be found under four headings:

(a) treaties or written international agreements binding upon States and international organizations under international law;

(b) customs as evidenced by general practice of States widespread, consistent and accepted as binding by States (opinio juris);

(c) general principles of private law, recognized by the major legal systems of the world; and 
(d) judicial decisions and writings of the most highly qualified publicists, as subsidiary means.

\section{(a) Treaties}

Outstanding among treaties are codification conventions such as the 1982 United Nations Convention on the Law of the Sea; the 1961 Vienna Convention on Diplomatic Relations; the 1963 Vienna Convention on Consular Relations; and the 1969 Vienna Convention on the Law of Treaties.

These Conventions contain provisions which are declaratory of existing rules of international law as supported by the practice of States, as well as other provisions which constitute progressive development, projecting future trends of international law.

The links between uniform law and international law are twofold. First, the achievement of unification of private law through Treaties serves as a linkage between the two disciplines, while the examination and comparison of the practice forms an essential part of the search for rules of customary international law. Codification conventions neither legislate nor create law, but merely restate or declare the existing rules of international law or reformulate them when necessary and regroup them in a systematic manner so as to merit the nomenclature "codification" without any legislative effect.

It is in a way not dissimilar from codification conventions that uniform law or model laws or an international treaty designed to unify a particular branch or area of private law serve to identify its diverse contents, if not to promote uniformity in substantive rules of national laws. In more ways than one, the work of codification of international law consisting of a survey of State practice, including governmental, legislative and judicial practice, is not so very different from the comparison of national laws in practice in different legal systems to determine the likelihood of their similarities, their uniformity or the harmonious result of their respective application.

\section{(b) Customs}

Evidence of State practice for an appreciable duration of time, reinforced by a sense of obligation incumbent upon the States to perform a particular act or omission, is a source of international law.

To establish the existence of a rule of customary international law, a norm-formulating agency such as the International Law Commission has to examine in depth the practice of the executive, the legislative and the judicial branches of the Government of various States. This task is one also performed by UNIDRO IT in quest of uniform law or unification of private law. While customary rules of international law relate primarily to legal norms binding on the States, uniform law is law to be followed by individuals and corporations in national legal systems. Their formation and constitution are nevertheless broadly similar.

\section{(c) General principles of law}

As a source of public international law, general principles of private law constitute another intricate link between national laws or the general principles commonly found 
in private law and rules of international law. To be precise, in the absence of a relevant provision of a treaty in force between States and failing the existence of a pertinent rule of customary international law applicable to a particular situation, relations between States are governed also by general principles commonly relevant in national or municipal laws such as good faith, natural justice and the need to hear both sides of the story or both parties to the dispute.

An examination of general principles of private law in the search for an applicable rule of international law is as such identical with a method used by comparatists searching for uniform laws or the potential of unification or harmonization of national laws on a particular topic.

(d) Judicial decisions and writings of publicists

Obviously, judicial decisions in any legal system are of persuasive, if not decisive authority of a legal proposition in any national or international system of law. This heading of sources of law appears serviceable not only for public international law, but also for national and international private law, including economic, financial, business and trade law.

Writings of the most highly qualified publicists constitute evidentiary sources providing subsidiary means of identifying existing rules of international law: not their formulation, but confirmation or proof of their existence and application. Such writings of publicists as well as privatists equally afford probative evidence of the existence of rules of law in any organized society, national and international. The task of identifying or establishing such rules is the same for the International Law Commission in regard to inter-governmental relations as it is for UNIDROIT in regard to international and transnational legal relations.

Thus, there exists an area of overlap where the functions of a norm-formulating agency such as the Commission and those performed by the Institute are clearly parallel, if not exactly identical. They are highly comparable and the methods of work are often indistinguishable.

\section{IV. - SIMILARITIES OF WORKING METHODS}

It is clear that in the ultimate analysis the final method, namely the adoption of a codification Convention by a diplomatic Conference or Conference of Plenipotentiaries, may be employed to achieve the international status of a general agreement among nations or States that their actions are guided by the agreed principles or, in the case of uniform law, that member States agree to adopt legislation to give effect to the principles which will govern relations among their nationals and corporations. The only difference is that ratification of a Convention by a State signifies its acceptance of an obligation of result, while in the case of uniform law it is possibly an obligation of conduct, i,e., to legislate accordingly.

0 ther options are equally open to both the Commission and the Institute. Certain sets of rules or principles could be adopted as model laws, such as draft articles on the "Most-Favored Nation Clauses" or draft instruments not destined for adoption by a Conference of Plenipotentiaries but only as a Code of Conduct for multinational corporations or other subjects of international law. 
Parallel possibilities exist for UNIDROIT, the United Nations Commission for International Trade Law (UNCITRAL) or the Hague Conference on Private International Law to adopt model rules of arbitration or arbitral procedures, or general principles of commercial contracts or lex mercatoria.

As to methodology, the International Law Commission traditionally prefers the appointment of an expert or specialist in the field to serve as Special Rapporteur on a particular topic. The Rapporteur submits an annual report for the consideration and preparation of draft articles which might afford a working basis for processing and adoption after two readings by the Commission through its Drafting Committee. There is periodic screening by Governments at the annual meetings of the Sixth Committee of the General Assembly of the United Nations. Also used are the replies to questionnaires prepared by the Commission and its Secretariat. Very rarely a working group is appointed to examine or review a particular topic which may end up in the Drafting Committee and the General Assembly.

The methodology adopted by UNIDROIT is broadly similar. The differences, if any, are in the mechanisms involved. The Governing Council has a controlling authority over the choice of topics to be studied and the direction of the studies to be made.

The establishment of a W orking or Study Group is more common than in the case of the International Law Commission and due attention is paid as regards its membership to a balanced representation of the various political, economic and legal systems.

In time, it is hoped that the interests of the peoples in what has been termed the Third World - i.e., neither East nor West, nor indeed Socialist, but more essentially the Asian, African, Latin American and Caribbean worlds whose legal systems in part reflect broad religious principles - may be given greater consideration. Their ideologies and usages should equally be reflected in the formulation of universal norms for global usage in order to embrace humanity as a whole, a reflection that has become or is becoming a living reality in international law, at least in the field of its progressive development. The business community of today will follow suit, also in respect of the creative evolution of transnational commercial norms and practices.

\section{V. - MERG ER OF UNIFICATION OF PRIVATE LAW AND THE PROCESS OF CODIFICATION AND PRO G RESSIVE DEVELO PMENT OF INTERNATIO NAL LAW}

More and more the trends of today and tomorrow seem to favor an inductive rather than a legislative or deductive method of work. An empirical approach appears to have been followed in the making of international law at the stage of codification of existing rules as well as at the more advanced stage of projecting future development or evolution of norms to be accepted in the general practice of States.

Likewise, UNIDROIT cannot and does not seek to impose its own theoretical standard on the international community but instead attempts to verify existing practices which may well still vary in minute details, but which indicate some semblance of commonalty of principles which are either identifiable, assimilable or at least reconcilable to ensure harmonious, if not identical, results in their application.

The trends in the evolution of international law through codification and progressive development are essentially parallel to those currently prevailing in the unification efforts 
in search of generally acceptable principles of uniform law to be followed in practice, not only by States in their legislative, executive and judicial functions but more importantly, by the business community, whose legal and business practice clearly contributes to the formulation and molding of uniform law as a natural extension of comparative law.

As has been amply demonstrated, the use of comparative law and frequent recourse to comparative law techniques in verifying and ascertaining the practice of States or particular rules of conduct under a national legal system are increasingly recognized as an essential part of the working methods of norm-formulating agencies of the world such as the International Law Commission, and of the findings of UNIDROIT as an authority on uniform law.

There is clearly a rising awareness of the comparative values of national legal systems and their relevance in the projection and formulation of international norms in a way not entirely dissimilar to the search for uniform law. The object and purpose of the two agencies are so closely tied up that they are, in part, essentially merged to produce a distinctive blend that contains common traits and characteristics for both codification and unification Conventions. Only the end result may differ according to the paths leading to each destination.

\section{VI. - CONCLUSION}

It is for the reasons outlined in the preceding pages that we may view with awe and admiration the constructive work in the field of codification and progressive development of international law carried out and conducted by the International Law Commission on the one hand, and the unification of private law or the projection of rules for uniform law or model law carried out and under study by U NIDRO IT on the other hand.

It is our hope that somewhere in the process, the work of both bodies will draw necessary inspiration from the experience, background, survey and preliminary studies made by each of the sister norm-formulating agencies in related fields.

In many areas of study and inquiry by the Commission, such as consular relations, jurisdictional immunities of States and their priority and the treatment of foreign investments and international organizations, rules of private international law prevailing in several legal systems are to be consulted and taken into consideration, entailing an overlap in substantial parts between the work of the Commission and that of UNIDROIT as well as that of UNCITRAL, the Hague Conference and other norm-formulating agencies. Their untiring efforts should bear fruit and provide useful lessons for the rest of the agencies working in related fields of study.

A particular entreaty is made to these worthy agencies to join forces in their common endeavors with a view to conserving their collective energy, enhancing their productive capacity and reaping the fullest benefits of whatever duplication and overlap of work appear necessary to attain their common aims and achievements. After all, it is ultimately the international community, through its individual as well as its collective or national members, that stands to gain from the conservation of international energy in the codification and unification effort for the betterment of mankind through the fostering of improved standards of international law as well as uniform national laws in the essential areas of global trade and investment and business relations. 
A final acknowledgment is due to $\mathrm{Mr}$ Malcolm Evans who, through his personal dedication and selfless service as Secretary General of UNIDROIT, made an invaluable contribution to this international effort. The international community is gratefully enjoying the fruits of the Institute's achievements, which have in no small measure been rendered possible by the untiring and ceaseless efforts of the head of its Secretariat and staff.

GS 